\title{
ANALISIS PENYEBAB BANJIR DAN SOULSINYA PADA PERUMAHAN KFT- CENGKARENG BARAT
}

\author{
Christian $^{1}$ dan Wati Asriningsih Pranoto ${ }^{2}$ \\ ${ }^{1}$ Program Studi Sarjana Teknik Sipil, Universitas Tarumanagara, Jl. Letjen S. Parman No.1 Jakarta \\ Christian.325160178@stu.untar.ac.id \\ ${ }^{2}$ Program Studi Sarjana Teknik Sipil, Universitas Tarumanagara, Jl. Letjen S. Parman No.1 Jakarta \\ Watip@ft.untar.ac.id
}

Masuk: 08-01-2021, revisi: 02-03-2021, diterima untuk diterbitkan: 23-04-2021

\begin{abstract}
One of the catalysm often found, causes by many factors and raises disruption of activities, to damaged of facilities and infrastructures is flood. Karyawan Film dan Televisi (KFT) Housing - West Cengkareng is one of the housing that often affected by flood. This thesis aims to find out the factors that cause floods in Perumahan KFT so can find the solutions. The data obtained were taken from BMKG, West Jakarta City Water Resources Department, and direct measurements in the review area. Rainfall analysis with data compatibility using Chi-Square and KolmogorovSmirnov methods to used at Rainfall capacity that analyzed by Mononobe method. Capacity of exsisting channels was analyzed by Manning method and capacity of planning channels was analyzed by Rasional method. On 2 year period have 13 of 84 channles that unable accommodate rainfall while on 1-3 January 2020 have 23 of 84 channels that unable accommodate rainfall. Analyzes result concluded that the flood factors in KFT housing - West Cengkareng was caused by the lack of existing canals capacity, low and sunken topography, garbage and the sediment at the bottom of the channel. Solutions to do are enlarge drainage channels and add more pump.
\end{abstract}

Keywords: flood; drainage; Manning; Rasional

\begin{abstract}
ABSTRAK
Salah satu bencana alam paling umum, yang terjadi karena berbagai sebab, serta menimbulkan kerugian seperti terganggunya aktifitas, hingga rusaknya sarana dan prasarana ialah banjir. Perumahan Karyawan Televisi dan Film (KFT) - Cengkareng Barat adalah salah satu perumahan yang sering terdampak banjir. Penelitian ini bertujuan untuk mencari solusi terhadap faktor penyebab terjadinya banjir di daerah Perumahan KFT. Data-data yang diperoleh diambil dari BMKG, Suku Dinas Sumber Daya Air Kota Jakarta Barat, dan pengukuran langsung di daerah tinjauan.Curah hujan dianalisis dengan uji kecocokan menggunakan metode Chi-Square dan Kolmogorov-Smirnov untuk menentukan jenis distribusi yang digunakan di Intensitas hujan dengan metode Mononobe. Kapasitas saluran eksisiting dianalisis dengan Metode Manning dan kapasitas saluran rencana dianalisis dengan metode Rasional untuk mengetahui debitnya. Pada periode 2 tahun terdapat 13 dari 84 saluran yang tidak mampu menampung curah hujan pada periode 1-3 Januari 2020 terdapat 23 dari 84 saluran yang tidak mampu menampung curah hujan. Dari hasil analisa didapatkan penyebab banjir di kawasan Perumahan KFT - Cengkareng Barat adalah kurangnya kapasitas saluran eksisting yang kurang memadai, kontur wilayah yang mempunyai ketinggian yang sama, dan sampah di dasar saluran. Solusi yang dapat dilakukan dengan memperbesar saluran drainase dan menambah pompa.
\end{abstract}

Kata kunci: banjir; drainase; Manning; Rasional

\section{PENDAHULUAN}

Cengkareng Barat merupakan bagian dari Kecamatan Cengkareng, Jakarta Barat, Daerah Khusus Ibukota Jakarta, Indonesia. Cengkareng Barat berbatasan dengan Kelurahan Tegal Alur pada bagian Utara, Kelurahan Pegadungan dan Kalideres pada bagian Barat, Kelurahan Cengkareng Timur di bagian Timur dan Kelurahan Duri Kosambi di sebelah Selatan.Cengkareng Barat memiliki luas wilayah $3.61 \mathrm{~km}^{2}$ dengan jumlah penduduk 74.922 jiwa dan $25.593 \mathrm{KK}$. (Dinas Komunikasi, Informatika dan Statistik Pemprov DKI Jakarta, 2020).

Perumahan KFT merupakan singkatan dari Perumahan Karyawan Film dan Televisi. Perumahan KFT merupakan salah satu perumahan tertua di Kelurahan Cengkareng Barat. Perumahan KFT Mempunyai sistem drainase yang baik terdiri dari saluran pembuangan, saluran sekunder dan saluran tersier. Perumahan KFT sebagian besar 
daerahnya terdiri dari pemukiman penduduk dan objek perekonomian. Daerah ini mengalami genangan air pada tanggal 1 sampai dengan 3 Januari 2020. Sebaran titik banjir Kelurahan Cengkareng Barat ditampilkan dalam Gambar 1.

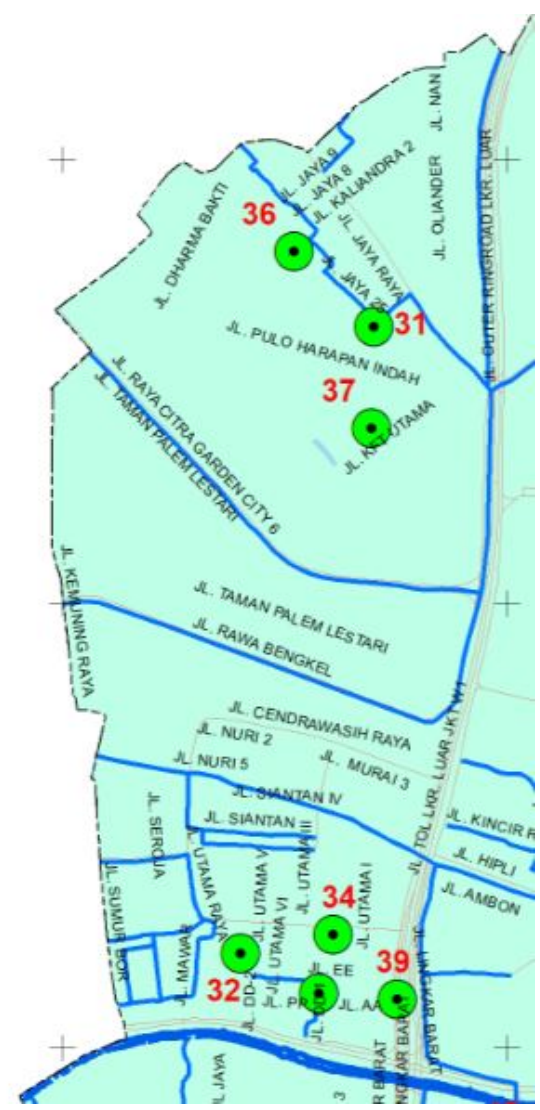

Gambar 1. Sebaran titik banjir Kelurahan Cengkareng Barat (Sumber: Suku Dinas Sumber Daya Air Kota Jakarta Barat, 2020)

Bedasarkan Gambar diatas, daerah yang diambil yaitu nomor 37 dimana merupakan daerah Perumahan KFT Cengkareng Barat.

Berdasarkan uraian yang dikemukakan diatas penulis merumuskan permasalahannya sebagai berikut:

1. Apakah kapasitas saluran eksisting dapat menampung debit air dari curah hujan yang terjadi pada tanggal 1 sampai 3 Januari 2020?

2. Periode ulang berapa yang digunakan dalam perhitungan debit saluran eksisting?

3. Apa penyebab genangan air yang terjadi di Perumahan KFT?

4. Apakah solusi atau penanganan yang dapat dilakukan agar banjir tidak terulang?

Tujuan penelitian yang didapatkan bedasarkan rumusan masalah adalah sebagai berikut:

1. Mengetahui kapasitas saluran eksisting dapat menampung debit air dari curah hujan yang terjadi pada tanggal 1 sampai 3 Januari 2020

2. Mengetahui periode ulang berapa yang digunakan dalam perhitungan debit saluran eksisting

3. Mengetahui penyebab genangan air yang terjadi di Perumahan KFT

4. Mengetahui Solusi atau penanganan yang dapat dilakukan agar banjir tidak terulang

\section{Analisis hidraulika}

Analisa hidrolika diperlukan untuk merencanakan dimensi saluran drainase yang dapat menampung limpasan baik dari tinjauan hidrolis maupun dari elevasi lapangan. Terdapat beberapa hal dalam analasis hidraulika sebagai berikut. (Suripin, 2004) 


\section{Penampang saluran segi empat}

Rumus yang digunakan untuk menentukan dimensi saluran segi empat adalah sebagai berikut :

1. Luas Penampang saluran segi empat

$$
\mathrm{A}=\mathrm{b}+\mathrm{h}
$$

2. Keliling Saluran segi empat

$$
\mathrm{P}=\mathrm{b}+2 \mathrm{~h}
$$

3. Jari-jari hidrolis saluran segi empat

$$
\mathrm{R}=\frac{A}{P}
$$

\section{Kecepatan aliran (V)}

Untuk memperhitungkan kecepatan aliran dalam perhitungan kapasitas saluran yang direncanakan, digunakan rumus kecepatan manning.

$$
\mathrm{V}=\frac{1}{n} R^{\frac{2}{3}} I^{\frac{1}{2}}
$$

\section{Debit aliran (Q)}

Untuk menghitung kapasitas saluran digunakan persamaan kontinuitas.

$$
\mathrm{Q}=\mathrm{A} \mathrm{V}
$$

dengan $\mathrm{Q}=$ Debit saluran $\left(\mathrm{m}^{3} / \mathrm{s}\right), \mathrm{V}=$ Kecepatan aliran $(\mathrm{m} / \mathrm{s}), \mathrm{A}=$ Luas basah saluran $\left(\mathrm{m}^{2}\right), \mathrm{P}=$ Keliling basah saluran (m) , R = Jari-jari hidrolis (m), I = Kemiringan dasar saluran , b = Lebar dasar saluran (m) , h $=$ Tinggi saluran (m)

\section{Uji Distribusi dan Fungsi Distribusi}

Terdapat 4 jenis distribusi untuk menghitung curah hujan yaitu Distribusi Normal, Distribusi Log Normal, Distribusi Log Pearson III, dan Distribusi Gumbel. (Upono dan Kusumawardani, 2016)

\section{Distribusi Normal}

Distribusi Normal bertujuan untuk menganalisis frekuensi curah hujan, analisis statistik berdasarkan distribusi curah hujan tahunan, debit rata-rata tahunan. Sebaran normal atau kurva normal disebut juga sebagai sebaran Gauss. Rumus yang digunakan dalam perhitungan adalah:

$$
\log X_{t}=\bar{X}+K_{t} \cdot S_{X}
$$

dengan $X_{t}=$ curah hujan rencana $(\mathrm{mm} / \mathrm{hari}), \overline{\mathrm{X}}=$ curah hujan maksimum rata-rata $(\mathrm{mm} / \mathrm{hari}), \mathrm{S}_{\mathrm{x}}=$ standar deviasi, dan $\mathrm{z}=$ faktor frekuensi.

\section{Distribusi Log Normal}

Distribusi Log Norma merupakan hasil transformasi dari distribusi normal, dengan mengubah varian X menjadi nilai logaritmik varian X. Rumus yang digunakan dalam perhitungan metode ini adalah sebagai berikut:

$$
\log X_{t}=\bar{X}+K_{t} \cdot S_{x}
$$

dengan $\log \mathrm{X}_{\mathrm{t}}=$ Besarnya curah hujan yang mungkin terjadi pada periode ulang $\mathrm{T}$ tahun $(\mathrm{mm} / \mathrm{hari}), \overline{\mathrm{X}}=$ Curah Hujan Maksimum rata-rata (mm/hari), $\mathrm{K}_{\mathrm{t}}=$ standar variabel , dan $\mathrm{S}_{\mathrm{x}}=$ standar deviasi.

3. Distribusi Log Pearson III

Distribusi ini merupakan hasil transformasi dari distribusi Pearson III dengan merubah varian $\mathrm{x}$ menjadi nilai log varian $\mathrm{x}$. Hujan rencana kala ulang $\mathrm{T}$ (tahun) dihitung dengan menggunakan anti log.

- Menghitung harga rata-rata dengan rumus:

$$
\log \overline{\mathrm{X}}=\frac{\sum_{\mathrm{i}=1}^{\mathrm{n}} \log \left(\mathrm{X}_{\mathrm{i}}\right)}{\mathrm{n}}
$$

Dengan $\log \bar{X}=$ harga rata-rata logaritma, $X_{i}=$ Nilai curah hujan, dan $\mathrm{n}=$ jumlah data.

- Menghitung logaritma hujan rencana dengan periode ulang $\mathrm{T}$ tahun dengan rumus : 
dengan $\mathrm{S}=$ Standar deviasi

$$
\mathrm{S}=\frac{\sum_{\mathrm{i}=1}^{\mathrm{n}}\left\{\log \left(\mathrm{X}_{\mathrm{i}}\right)-\log (\overline{\mathrm{X}})\right\}^{2}}{\mathrm{n}-1}
$$

- Menghitung koefisien skewness (Cs) dengan rumus :

dengan Cs $=$ Koefisien Skewness

$$
\mathrm{C}_{\mathrm{S}}=\frac{\sum_{\mathrm{i}=1}^{\mathrm{n}}\left\{\log \left(\mathrm{X}_{\mathrm{i}}\right)-\log (\overline{\mathrm{X}})\right\}^{2}}{(\mathrm{n}-1)(\mathrm{n}-2) \mathrm{S}^{3}}
$$

- Menghitung logaritma hujan rencana dengan periode ulang T tahun dengan rumus :

$$
\begin{aligned}
\log Y & =\log \bar{X}+k \cdot S \\
X_{t} & =10^{(\log Y)}
\end{aligned}
$$

dengan $\mathrm{X}_{\mathrm{t}}=$ Curah hujan rencana periode ulang $\mathrm{T}$ tahun, $\mathrm{k}=$ Harga yang diperoleh bedasarkan nilai Cs dan $\mathrm{S}=$ standar deviasi

\section{Distribusi Gumbel}

Distribusi Gumbel digunakan untuk analisis data maksimum, sebagai contoh untuk analisis frekuensi banjir, dengan rumus sebagai berikut:

$$
\mathrm{X}_{\mathrm{t}}=\overline{\mathrm{X}}+\frac{\left(\mathrm{Y}_{\mathrm{t}}-\mathrm{Y}_{\mathrm{n}}\right)}{\mathrm{S}_{\mathrm{n}}} \times \mathrm{S}_{\mathrm{X}}
$$

dengan $\mathrm{Yt}=$ Reiduced variable, parameter Gumbel untuk periode $\mathrm{T}$ tahun, $\mathrm{Yn}=$ Reduced mean, merupakan fungsi dari banyaknya data dan $\mathrm{Sn}=$ Reduced standar deviasi, merupakan fungsi dari banyak data.

Jenis sebaran fungsi distribusi yang sering digunakan pada analisis frekuensi untuk hujan ekstrim di Indonesia adalah Uji Chi-Square dan Uji Kolmogorov-Smirnov. (SNI 2415:2016)

\section{Uji Chi-Square}

Metode ini menganggap pengamatan pembentukan variabel acak yang dilakukan secara statistik dengan mengikuti kurva distribusi Chi-Square dengan derajat kebebasan k-p-1, dengan p merupakan jumlah parameter yang diestimasi dari data. Uji statistik ini berdasarkan pada bobot jumlah kuadrat perbedaan antara pengamatan dan teoritisnya yang dibagi dalam kelompok kelas. Bandingkan $X^{2}$ hitungan dengan $X^{2}$ kritis, bila hitungan $X^{2}<X^{2}$ kritis, berarti metode distribusi yang diperiksa dapat diterima.

\section{Uji Kolmogorov-Smirnov}

Uji kecocokan ini merupakan uji kecocokan "non parametric" karena tidak mengikuti distribusi tertentu. Uji ini menghitung besarnya jarak maksimum secara vertikal antara pengamatan dan teoritis dari distribusi sampelnya. Distribusi dikatakan cocok jika nilai Dn $<$ D kritisnya pada derajat kepercayaan yang diinginkan.

\section{HEC-RAS}

HEC-RAS merupakan program aplikasi untuk memodelkan aliran air di sungai, River Analysis System (RAS). HECRAS merupakan model satu dimensi aliran permanen maupun tak permanen (Istiarto, 2014). Elemen penting dalam HEC-RAS adalah hitungan profil muka air aliran permanen, simulasi aliran air non permanen dan hitungan transport sedimen serta kualitas air tersebut menggunakan data geometri yang sama, routine hitungan hidraulika yang sama, serta berbagai fitur desain hidraulik yang dapat diakses setelah hitungan profil muka air berhasil dilakukan.

\section{METODE PENELITIAN PENGUMPULAN DATA}

\section{Pengumpulan data}

Data-data yang diperlukan terdiri dari:

1. Peta Lokasi Perumahan KFT, Kelurahan Cengkareng Barat dari Suku Dinas Sumber Daya Air Jakarta Barat.

2. Peta Sebaran Titik Banjir di Perumahan KFT dari Suku Dinas Sumber Daya Air Kota Jakarta Barat.

3. Data Curah Hujan Harian Maksimum stasiun Meteorologi Bandara Internasional Soekarno-Hatta selama 10 tahun yang diambil dari Badan Meteorologi Klimatologi dan Geofisika.

4. Peta Jaringan Drainase di Perumahan KFT - Kelurahan Cengkareng Barat dari Suku Dinas Sumber Daya Air Kota Jakarta Barat. 
5. Spesifikasi saluran eksisting di Perumahan KFT - Kelurahan Cengkareng Barat dari Suku Dinas Sumber Daya Air Kota Jakarta Barat serta pengukuran langsung di lapangan.

6. Peta Topografi Perumahan KFT - Kelurahan Cengkareng Barat dari Suku Dinas Sumber Daya Air Kota Jakarta Barat.

\section{Pengolahan data}

Berikut langkah-langkah pengolahan data yang dilakukan:

1. Melakukan perhitungan kapasitas saluran drainase eksisting.

2. Melakukan pengolahan data curah hujan yaitu dengan mengambil data curah hujan maksimum harian setiap tahun selama 10 tahun dari stasiun Meteorologi Bandara Internasional Soekarno-Hatta.

3. Melakukan pengujian kecocokan fungsi distribusi dengan menggunakan metode Chi-Square dan KolmogorovSmirnov untuk menentukan distribusi yang akan digunakan.

4. Melakukan perhitungan frekuensi curah hujan dengan distribusi yang sudah diuji dengan pengujian kecocokan fungsi distribusi yaitu dengan menggunakan Metode Distribusi Normal, Log Normal, Log Pearson III, dan Gumbel

5. Melakukan perhitungan intensitas hujan dengan metode Mononobe.

6. Menghitung debit rancangan dengan metode Rasional.

7. Melakukan pemodelan terhadap saluran eksisting dengan aplikasi HEC-RAS.

8. Menganalisis debit saluran eksisting apakah mampu menampung debit rancangan dengan metode Rasional atau tidak, jika tidak maka perlu direncanakan saluran drainase baru.

9. Menganalisis saluran drainase rencana.

10. Melakukan pemodelan terhadap saluran rencana dengan aplikasi $H E C-R A S$.

11. Memberikan kesimpulan dan saran terhadap analisa penyebab banjir.

\section{HASIL DAN PEMBAHASAN}

Pengujian distribusi dilakukan terhadap metode frekuensi curah hujan dengan Metode Normal, Log Normal, Gumbel dan Log Pearson III. Bedasarkan pengujian distribusi disimpulkan bahwa data curah hujan yang dimiliki dapat dianalisis dengan metode distribusi Log Pearson Tipe III karena memiliki persyaratan yang memenuhi.berikut ditampilkan dalam Tabel 1.

Tabel 1. Hasil Uji Distribusi

\begin{tabular}{cccc}
\hline Distribusi & Persyaratan & Hasil Perhitumgan & Keterangan \\
\hline Nornal & $\mathrm{Cs} \approx 0$ & 2.72597 & Tidak Memenuhi \\
& $\mathrm{Ck} \approx 3$ & 11.25626 & Tidak Memenuhi \\
Log Normal & $\mathrm{Cs} \approx 3 \mathrm{Cv}$ & $-0.1559 \neq 0.1494$ & Tidak Memenuhi \\
Gumbel & $\mathrm{Cs} \approx 1.1396$ & 2.72597 & Memenuhi \\
& $\mathrm{Ck} \leq 5.4002$ & 11.25626 & \\
Log Pearson III & $\mathrm{Cs} \neq 0$ & 1.51147 & \\
\hline
\end{tabular}

Setelah mendapatkan Uji Distribusi, kemudian dilakukan pengujian menggunakan Chi-Square dan KolmogorovSmirnov Hasil pengujian distribusi Chi-Square dan uji Kolmogorov-Smirnov dapat dilihat pada Tabel 2.

Tabel 2. Analisis distribusi

\begin{tabular}{|c|c|c|c|c|c|c|c|}
\hline \multirow{2}{*}{ No } & \multirow{2}{*}{ Distribusi } & \multicolumn{2}{|c|}{ Chi-Square } & \multirow{2}{*}{ Kesimpulan } & \multicolumn{2}{|c|}{ Kolmogorov-Smirnov } & \multirow{2}{*}{ Kesimpulan } \\
\hline & & $\mathrm{X}^{2}$ & $\mathrm{X}^{2} \mathrm{Cr}$ & & Do & Dmax & \\
\hline 1 & Normal & 5.991 & 24 & Tidak Diterima & 0.41 & 0.1212 & Diterima \\
\hline 2 & Log Normal & 5.991 & 6 & & 0.41 & 0.1258 & ma \\
\hline 3 & Log Pearson III & 5.991 & 2 & Dite & 0.41 & 0.1435 & Diterima \\
\hline 4 & Gumbel & 5.991 & 11 & Diterima & 0.41 & 0.4562 & Tidak Diterima \\
\hline
\end{tabular}

Curah hujan rencana digunakan periode ulang 2 tahun dengan pertimbangan luas daerah tangkapan berada diantara 10-50 ha (Menteri Pekerjaan Umum, 2014). Hasil perhitungan curah hujan yang dilakukan dapat dilihat pada Tabel 3. 
Tabel 3. Hasil perhitungan curah hujan dengan metode Log Pearson III

\begin{tabular}{cccc}
\hline Tahun & $\mathrm{k}$ & $\log \mathrm{Rr}$ & $\mathrm{Rr}(\mathrm{mm})$ \\
\hline 2 & -0.259 & 2.000476014 & 100.11 \\
5 & 0.6882 & 2.213319821 & 163.425 \\
10 & 1.332 & 2.357987097 & 228.027 \\
20 & 2.023 & 2.513260609 & 326.032 \\
25 & 2.145 & 2.540675036 & 347.276 \\
\hline
\end{tabular}

Penamaan saluran tersier dan sekunder dapat dilihat pada Gambar 2 dibawah ini.

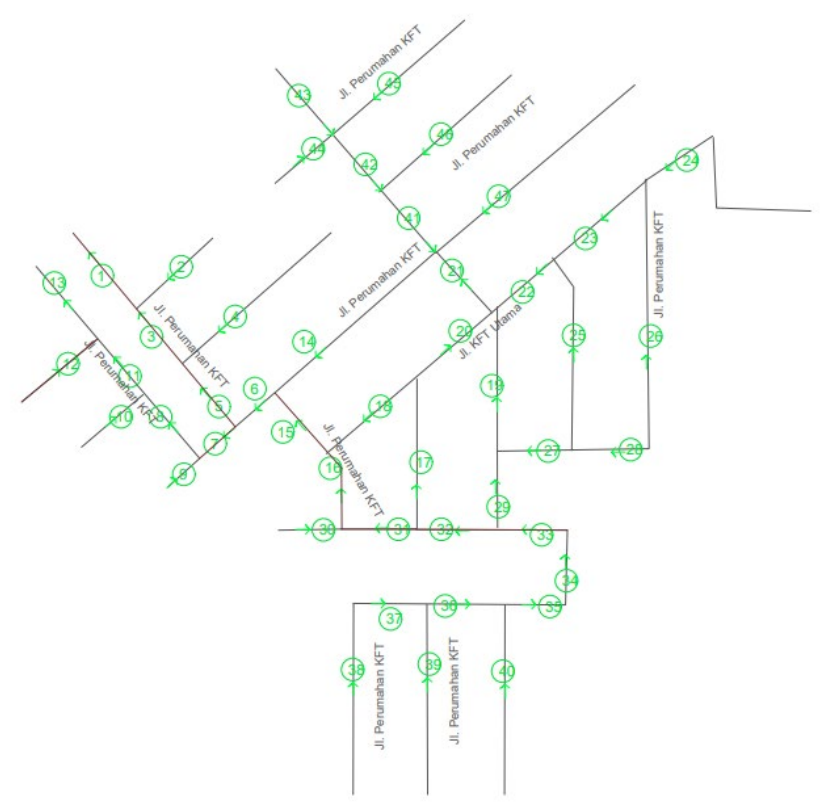

Gambar 2. Peta jaringan drainase wilayah Perumahan KFT

Perhitungan kapasitas saluran eksisting menggunakan tinggi jagaan $0.2 \mathrm{~m}$ dan koefisien kekasaran Manning 0.02 dengan jenis lapisan perkerasan beton seluruhnya (Haryono, 2016). Berikut ditampilkan Tabel 4 yang merupakan perhitungan kapasitas saluran eksisiting dengan rumus Manning.

Tabel 4 Perhitungan kapasitas saluran eksisting

\begin{tabular}{|c|c|c|c|c|c|c|c|c|c|}
\hline No Saluran & Posisi & $\begin{array}{c}\text { Panjang } \\
\text { (m) }\end{array}$ & $\mathrm{b}(\mathrm{m})$ & $\mathrm{h}(\mathrm{m})$ & Kemiringan & $\begin{array}{c}\text { A } \\
\left(\mathrm{m}^{2}\right)\end{array}$ & $\begin{array}{c}\mathrm{P} \\
(\mathrm{m})\end{array}$ & $\begin{array}{c}\mathrm{V} \\
(\mathrm{m} / \mathrm{s})\end{array}$ & $\begin{array}{l}\text { Debit } \\
\left(\mathrm{m}^{3} / \mathrm{s}\right)\end{array}$ \\
\hline 1 & $\begin{array}{c}\text { Kiri } \\
\text { Kanan }\end{array}$ & 42.83 & 0.6 & 0.8 & 0.0023 & 0.36 & 1.8 & 0.8263 & 0.2975 \\
\hline \multirow{2}{*}{2} & Kiri & 50.13 & 0.4 & 0.5 & 0.0040 & 0.12 & 1 & 0.7683 & 0.0922 \\
\hline & Kanan & 50.13 & 0.4 & 0.7 & 0.0020 & 0.2 & 1.4 & 0.6103 & 0.1221 \\
\hline 3 & $\begin{array}{c}\text { Kiri } \\
\text { Kanan }\end{array}$ & 40.56 & 0.6 & 0.8 & 0.0025 & 0.36 & 1.8 & 0.8491 & 0.3057 \\
\hline \multirow{2}{*}{4} & Kiri & 54.85 & 0.5 & 0.5 & 0.0018 & 0.15 & 1.1 & 0.5656 & 0.0848 \\
\hline & Kanan & 54.85 & 0.5 & 0.5 & 0.0018 & 0.15 & 1.1 & 0.5656 & 0.0848 \\
\hline 5 & $\begin{array}{c}\text { Kiri } \\
\text { Kanan }\end{array}$ & 40.87 & 0.6 & 0.8 & 0.0024 & 0.36 & 1.8 & 0.8458 & 0.3045 \\
\hline \multirow{2}{*}{6} & Kiri & 31.14 & 0.8 & 0.55 & 0.0042 & 0.28 & 1.5 & 1.0552 & 0.2955 \\
\hline & Kanan & 31.14 & 0.8 & 0.55 & 0.0042 & 0.28 & 1.5 & 1.0552 & 0.2955 \\
\hline \multirow{2}{*}{7} & Kiri & 21.16 & 0.6 & 0.6 & 0.0028 & 0.24 & 1.4 & 0.8216 & 0.1972 \\
\hline & Kanan & 21.16 & 0.6 & 0.6 & 0.0028 & 0.24 & 1.4 & 0.8216 & 0.1972 \\
\hline 8 & $\begin{array}{c}\text { Kiri } \\
\text { Kanan }\end{array}$ & 44.77 & 0.6 & 0.8 & 0.0036 & 0.36 & 1.8 & 1.0222 & 0.3680 \\
\hline \multirow{2}{*}{9} & Kiri & 31.53 & 1 & 0.8 & 0.0048 & 0.6 & 2.2 & 1.4503 & 0.8702 \\
\hline & Kanan & 31.53 & 0.8 & 0.55 & 0.0035 & 0.28 & 1.5 & 0.9646 & 0.2701 \\
\hline
\end{tabular}


Tabel 4 Perhitungan kapasitas saluran eksisting (Lanjutan)

\begin{tabular}{|c|c|c|c|c|c|c|c|c|c|}
\hline No Saluran & Posisi & $\begin{array}{c}\text { Panjang } \\
\text { (m) }\end{array}$ & $\mathrm{b}(\mathrm{m})$ & $\mathrm{h}(\mathrm{m})$ & Kemiringan & $\begin{array}{c}\text { A } \\
\left(\mathrm{m}^{2}\right)\end{array}$ & $\begin{array}{c}\mathrm{P} \\
(\mathrm{m})\end{array}$ & $\begin{array}{c}\mathrm{V} \\
(\mathrm{m} / \mathrm{s})\end{array}$ & $\begin{array}{l}\text { Debit } \\
\left(\mathrm{m}^{3} / \mathrm{s}\right)\end{array}$ \\
\hline 10 & $\begin{array}{c}\text { Kiri } \\
\text { Kanan }\end{array}$ & 40.14 & 0.6 & 0.8 & 0.0040 & 0.36 & 1.8 & 1.0796 & 0.3887 \\
\hline \multirow{2}{*}{11} & Kiri & 51.18 & 0.4 & 0.5 & 0.0039 & 0.12 & 1 & 0.7604 & 0.0913 \\
\hline & Kanan & 51.18 & 0.4 & 0.7 & 0.0039 & 0.2 & 1.4 & 0.8542 & 0.1708 \\
\hline 12 & $\begin{array}{c}\text { Kiri } \\
\text { Kanan }\end{array}$ & 46.49 & 0.6 & 0.8 & 0.0043 & 0.36 & 1.8 & 1.1216 & 0.4038 \\
\hline \multirow{2}{*}{13} & Kiri & 58.54 & 0.5 & 0.6 & 0.0034 & 0.2 & 1.3 & 0.8391 & 0.1678 \\
\hline & Kanan & 58.54 & 0.5 & 0.6 & 0.0034 & 0.2 & 1.3 & 0.8391 & 0.1678 \\
\hline \multirow{2}{*}{14} & Kiri & 120.85 & 0.8 & 0.65 & 0.0009 & 0.36 & 1.7 & 0.5359 & 0.1929 \\
\hline & Kanan & 120.85 & 0.8 & 0.65 & 0.0009 & 0.36 & 1.7 & 0.5359 & 0.1929 \\
\hline 15 & $\begin{array}{c}\text { Kiri } \\
\text { Kanan }\end{array}$ & 40.89 & 0.5 & 0.55 & 0.0024 & 0.175 & 1.2 & 0.6851 & 0.1199 \\
\hline 16 & $\begin{array}{c}\text { Kiri } \\
\text { Kanan }\end{array}$ & 48.56 & 0.5 & 0.55 & 0.0021 & 0.175 & 1.2 & 0.6286 & 0.1100 \\
\hline \multirow{2}{*}{17} & Kiri & 93.46 & 0.6 & 0.65 & 0.0011 & 0.27 & 1.5 & 0.5214 & 0.1408 \\
\hline & Kanan & 93.46 & 0.6 & 0.6 & 0.0011 & 0.24 & 1.4 & 0.5047 & 0.1211 \\
\hline \multirow{2}{*}{18} & Kiri & 70.39 & 0.7 & 0.65 & 0.0014 & 0.315 & 1.6 & 0.6378 & 0.2009 \\
\hline & Kanan & 70.39 & 0.5 & 0.65 & 0.0014 & 0.225 & 1.4 & 0.5571 & 0.1253 \\
\hline \multirow{2}{*}{19} & Kiri & 85.91 & 0.6 & 0.65 & 0.0009 & 0.27 & 1.5 & 0.4864 & 0.1313 \\
\hline & Kanan & 85.91 & 0.6 & 0.65 & 0.0009 & 0.27 & 1.5 & 0.4864 & 0.1313 \\
\hline \multirow{2}{*}{20} & Kiri & 60.29 & 0.7 & 0.65 & 0.0017 & 0.315 & 1.6 & 0.6891 & 0.2171 \\
\hline & Kanan & 60.29 & 0.5 & 0.65 & 0.0017 & 0.225 & 1.4 & 0.6019 & 0.1354 \\
\hline \multirow{2}{*}{21} & Kiri & 48.55 & 0.6 & 0.65 & 0.0029 & 0.27 & 1.5 & 0.8560 & 0.2311 \\
\hline & Kanan & 48.55 & 0.6 & 0.65 & 0.0029 & 0.27 & 1.5 & 0.8560 & 0.2311 \\
\hline \multirow{2}{*}{22} & Kiri & 59.01 & 0.5 & 0.65 & 0.0017 & 0.225 & 1.4 & 0.6084 & 0.1369 \\
\hline & Kanan & 59.01 & 0.5 & 0.65 & 0.0017 & 0.225 & 1.4 & 0.6084 & 0.1369 \\
\hline \multirow{2}{*}{23} & Kiri & 70.84 & 0.5 & 0.65 & 0.0014 & 0.225 & 1.4 & 0.5553 & 0.1249 \\
\hline & Kanan & 70.84 & 0.5 & 0.65 & 0.0014 & 0.225 & 1.4 & 0.5553 & 0.1249 \\
\hline \multirow{2}{*}{24} & Kiri & 147.68 & 0.5 & 0.65 & 0.0007 & 0.225 & 1.4 & 0.3846 & 0.0865 \\
\hline & Kanan & 147.68 & 0.5 & 0.65 & 0.0007 & 0.225 & 1.4 & 0.3846 & 0.0865 \\
\hline \multirow{2}{*}{25} & Kiri & 117.64 & 0.4 & 0.65 & 0.0003 & 0.18 & 1.3 & 0.2468 & 0.0444 \\
\hline & Kanan & 117.64 & 0.4 & 0.65 & 0.0003 & 0.18 & 1.3 & 0.2468 & 0.0444 \\
\hline \multirow{2}{*}{26} & Kiri & 161.54 & 0.6 & 0.65 & 0.0002 & 0.27 & 1.5 & 0.2508 & 0.0677 \\
\hline & Kanan & 161.54 & 0.6 & 0.65 & 0.0002 & 0.27 & 1.5 & 0.2508 & 0.0677 \\
\hline \multirow{2}{*}{27} & Kiri & 49.98 & 0.3 & 0.75 & 0.0020 & 0.165 & 1.4 & 0.5376 & 0.0887 \\
\hline & Kanan & 49.98 & 0.4 & 0.8 & 0.0020 & 0.22 & 1.5 & 0.6220 & 0.1368 \\
\hline \multirow{2}{*}{28} & Kiri & 43.01 & 0.3 & 0.75 & 0.0023 & 0.165 & 1.5 & 0.5795 & 0.0956 \\
\hline & Kanan & 43.01 & 0.4 & 0.75 & 0.0023 & 0.22 & 1.5 & 0.6705 & 0.1475 \\
\hline & Kiri & 48.9 & 0.6 & 0.65 & 0.0016 & 0.27 & 1.5 & 0.6447 & 0.1741 \\
\hline 29 & Kanan & 48.9 & 0.6 & 0.65 & 0.0016 & 0.27 & 1.5 & 0.6447 & 0.1741 \\
\hline 30 & Kiri & 37.43 & 0.4 & 0.65 & 0.0021 & 0.18 & 1.3 & 0.6187 & 0.1114 \\
\hline 30 & Kanan & 37.43 & 0.5 & 0.8 & 0.0027 & 0.275 & 1.6 & 0.7989 & 0.2197 \\
\hline & Kiri & 50.96 & 0.4 & 0.65 & 0.0016 & 0.18 & 1.3 & 0.5302 & 0.0954 \\
\hline 31 & Kanan & 50.96 & 0.5 & 0.75 & 0.0020 & 0.275 & 1.6 & 0.6847 & 0.1883 \\
\hline & Kiri & 47.26 & 0.4 & 0.65 & 0.0017 & 0.18 & 1.3 & 0.5506 & 0.0991 \\
\hline 32 & Kanan & 47.26 & 0.5 & 0.75 & 0.0021 & 0.275 & 1.6 & 0.7110 & 0.1955 \\
\hline & Kiri & 43.4 & 0.4 & 0.65 & 0.0018 & 0.18 & 1.3 & 0.5745 & 0.1034 \\
\hline 33 & Kanan & 43.4 & 0.5 & 0.8 & 0.0023 & 0.275 & 1.6 & 0.7419 & 0.2040 \\
\hline 34 & Kiri & & & & & & & & \\
\hline 34 & Kanan & 49.46 & 0.4 & 0.65 & 0.0020 & 0.18 & 1.3 & 0.6017 & 0.1083 \\
\hline & Kiri & 37.55 & 0.4 & 0.65 & 0.0032 & 0.18 & 1.3 & 0.7565 & 0.1362 \\
\hline 35 & Kanan & 37.55 & 0.4 & 0.65 & 0.0032 & 0.18 & 1.3 & 0.7565 & 0.1362 \\
\hline & Kiri & 47.69 & 0.4 & 0.65 & 0.0025 & 0.18 & 1.3 & 0.6713 & 0.1208 \\
\hline 36 & Kanan & 47.69 & 0.4 & 0.7 & 0.0025 & 0.18 & 1.3 & 0.6713 & 0.1208 \\
\hline
\end{tabular}


Tabel 4. Perhitungan Kapasitas Saluran Eksisting (Lanjutan)

\begin{tabular}{|c|c|c|c|c|c|c|c|c|c|}
\hline No Saluran & Posisi & $\begin{array}{c}\text { Panjang } \\
\text { (m) }\end{array}$ & $\mathrm{b}(\mathrm{m})$ & $\mathrm{h}(\mathrm{m})$ & Kemiringan & $\begin{array}{c}\mathrm{A} \\
\left(\mathrm{m}^{2}\right)\end{array}$ & $\begin{array}{l}\mathrm{P} \\
(\mathrm{m})\end{array}$ & $\begin{array}{c}\mathrm{V} \\
(\mathrm{m} / \mathrm{s})\end{array}$ & $\begin{array}{l}\text { Debit } \\
\left(\mathrm{m}^{3} / \mathrm{s}\right)\end{array}$ \\
\hline \multirow{2}{*}{37} & Kiri & 46.66 & 0.4 & 0.65 & 0.0026 & 0.18 & 1.3 & 0.6786 & 0.1222 \\
\hline & Kanan & 46.66 & 0.4 & 0.65 & 0.0026 & 0.18 & 1.3 & 0.6786 & 0.1222 \\
\hline \multirow{2}{*}{38} & Kiri & 115.74 & 0.4 & 0.65 & 0.0009 & 0.18 & 1.3 & 0.3934 & 0.0708 \\
\hline & Kanan & 115.74 & 0.4 & 0.7 & 0.0009 & 0.18 & 1.3 & 0.3934 & 0.0708 \\
\hline \multirow{2}{*}{39} & Kiri & 117.54 & 0.5 & 0.65 & 0.0009 & 0.225 & 1.4 & 0.4311 & 0.0970 \\
\hline & Kanan & 117.54 & 0.5 & 0.7 & 0.0009 & 0.225 & 1.4 & 0.4311 & 0.0970 \\
\hline \multirow{2}{*}{40} & Kiri & 113.05 & 0.7 & 0.65 & 0.0009 & 0.315 & 1.6 & 0.5033 & 0.1585 \\
\hline & Kanan & 113.05 & 0.7 & 0.7 & 0.0009 & 0.315 & 1.6 & 0.5033 & 0.1585 \\
\hline \multirow{2}{*}{41} & Kiri & 51.83 & 0.8 & 0.7 & 0.0029 & 0.4 & 1.8 & 0.9868 & 0.3947 \\
\hline & Kanan & 51.83 & 0.6 & 0.7 & 0.0029 & 0.3 & 1.6 & 0.8812 & 0.2644 \\
\hline \multirow{2}{*}{42} & Kiri & 47.92 & 0.8 & 0.7 & 0.0031 & 0.4 & 1.8 & 1.0263 & 0.4105 \\
\hline & Kanan & 47.92 & 0.6 & 0.7 & 0.0031 & 0.3 & 1.6 & 0.9164 & 0.2749 \\
\hline \multirow{2}{*}{43} & Kiri & 49.93 & 0.8 & 0.7 & 0.0030 & 0.4 & 1.8 & 1.0054 & 0.4022 \\
\hline & Kanan & 49.93 & 0.6 & 0.7 & 0.0030 & 0.3 & 1.6 & 0.8978 & 0.2693 \\
\hline \multirow{2}{*}{44} & Kiri & & & & & & & & \\
\hline & Kanan & 42.8 & 0.5 & 0.7 & 0.0014 & 0.25 & 1.5 & 0.5670 & 0.1417 \\
\hline \multirow{2}{*}{45} & Kiri & 97.7 & 0.5 & 0.65 & 0.0010 & 0.225 & 1.4 & 0.4729 & 0.1064 \\
\hline & Kanan & 97.7 & 0.5 & 0.7 & 0.0010 & 0.225 & 1.4 & 0.4729 & 0.1064 \\
\hline \multirow{2}{*}{46} & Kiri & 116.53 & 0.5 & 0.65 & 0.0009 & 0.225 & 1.4 & 0.4330 & 0.0974 \\
\hline & Kanan & 116.53 & 0.5 & 0.7 & 0.0009 & 0.225 & 1.4 & 0.4330 & 0.0974 \\
\hline \multirow{2}{*}{47} & Kiri & 153.39 & 0.8 & 0.65 & 0.0007 & 0.36 & 1.7 & 0.4757 & 0.1713 \\
\hline & Kanan & 153.39 & 0.8 & 0.7 & 0.0007 & 0.36 & 1.7 & 0.4757 & 0.1713 \\
\hline
\end{tabular}

Intensitas hujan menggunakan rumus Mononobe dengan periode ulang 2 tahun dan didapatkan curah hujan (Rr) sebesari $100.11 \mathrm{~mm}$. Debit rencana menggunakan metode rasional Luas daerah tangkapan didapat dari pengukuran luas lahan berdasarkan arah aliran yang didapat dari pengamatan langsung di lapangan. Berikut ditampilkan Tabel 5 mengenai perhitungan intensitas hujan dan debit rencana.

Tabel 5. Perhitungan insensitas hujan dan debit rencana

\begin{tabular}{|c|c|c|c|c|c|c|}
\hline $\begin{array}{c}\text { No } \\
\text { Saluran }\end{array}$ & Posisi & Tc & $\begin{array}{l}\text { Intensitas } \\
(\mathrm{mm} / \mathrm{jam})\end{array}$ & $\mathrm{C}$ & $\begin{array}{c}\text { A } \\
\text { Kumulatif } \\
(\mathrm{Ha})\end{array}$ & $\begin{array}{l}\text { Debit } \\
\left(\mathrm{m}^{3} / \mathrm{s}\right)\end{array}$ \\
\hline 1 & $\begin{array}{c}\text { Kiri } \\
\text { Kanan }\end{array}$ & 0.2268 & 93.30781 & 0.44 & 4.81776 & 0.54987 \\
\hline \multirow{2}{*}{2} & Kiri & 0.2024 & 100.67414 & 0.44 & 0.09962 & 0.01227 \\
\hline & Kanan & 0.1913 & 104.53148 & 0.44 & 0.09908 & 0.01267 \\
\hline 3 & $\begin{array}{c}\text { Kiri } \\
\text { Kanan }\end{array}$ & 0.2248 & 93.87529 & 0.44 & 4.67017 & 0.53627 \\
\hline \multirow{2}{*}{4} & Kiri & 0.2119 & 97.65189 & 0.44 & 0.16097 & 0.01923 \\
\hline & Kanan & 0.2119 & 97.65189 & 0.44 & 0.15910 & 0.01900 \\
\hline 5 & $\begin{array}{c}\text { Kiri } \\
\text { Kanan }\end{array}$ & 0.2150 & 96.70414 & 0.44 & 4.46686 & 0.52838 \\
\hline \multirow{2}{*}{6} & Kiri & 0.2134 & 97.17598 & 0.44 & 2.19058 & 0.26038 \\
\hline & Kanan & 0.1956 & 102.98902 & 0.44 & 1.09306 & 0.13770 \\
\hline \multirow{2}{*}{7} & Kiri & 0.1483 & 123.85404 & 0.44 & 2.20298 & 0.33375 \\
\hline & Kanan & 0.1335 & 132.89365 & 0.44 & 1.12934 & 0.18358 \\
\hline 8 & $\begin{array}{c}\text { Kiri } \\
\text { Kanan }\end{array}$ & 0.1783 & 109.55852 & 0.44 & 2.28587 & 0.30633 \\
\hline \multirow{2}{*}{9} & Kiri & 0.1225 & 140.69420 & 0.44 & 0.02376 & 0.00409 \\
\hline & Kanan & 0.1266 & 137.64774 & 0.44 & 0.00892 & 0.00150 \\
\hline 10 & $\begin{array}{c}\text { Kiri } \\
\text { Kanan }\end{array}$ & 0.1819 & 108.09789 & 0.44 & 2.36643 & 0.31290 \\
\hline \multirow{2}{*}{11} & Kiri & 0.1863 & 106.37984 & 0.44 & 0.06340 & 0.00825 \\
\hline & Kanan & 0.1846 & 107.03311 & 0.44 & 0.06619 & 0.00867 \\
\hline
\end{tabular}


Tabel 5. Perhitungan intensitas hujan dan debit rencana (Lanjutan)

\begin{tabular}{|c|c|c|c|c|c|c|}
\hline $\begin{array}{c}\text { No } \\
\text { Saluran }\end{array}$ & Posisi & $\mathrm{Tc}$ & $\begin{array}{l}\text { Intensitas } \\
(\mathrm{mm} / \mathrm{jam})\end{array}$ & $\mathrm{C}$ & $\begin{array}{c}\text { A } \\
\text { Kumulatif } \\
(\mathrm{Ha})\end{array}$ & $\begin{array}{l}\text { Debit } \\
\left(\mathrm{m}^{3} / \mathrm{s}\right)\end{array}$ \\
\hline 12 & $\begin{array}{c}\text { Kiri } \\
\text { Kanan }\end{array}$ & 0.1952 & 103.13559 & 0.44 & 2.49361 & 0.31458 \\
\hline \multirow{2}{*}{13} & Kiri & 0.2043 & 100.04103 & 0.44 & 0.07807 & 0.00955 \\
\hline & Kanan & 0.2043 & 100.04103 & 0.44 & 0.07807 & 0.00955 \\
\hline \multirow{2}{*}{14} & Kiri & 0.4843 & 56.27330 & 0.44 & 0.66633 & 0.04587 \\
\hline & Kanan & 0.4875 & 56.03199 & 0.44 & 1.03343 & 0.07083 \\
\hline 15 & $\begin{array}{c}\text { Kiri } \\
\text { Kanan }\end{array}$ & 0.2249 & 93.85306 & 0.44 & 1.46380 & 0.16805 \\
\hline 16 & $\begin{array}{c}\text { Kiri } \\
\text { Kanan }\end{array}$ & 0.2366 & 90.72791 & 0.44 & 1.42124 & 0.15773 \\
\hline \multirow{2}{*}{17} & Kiri & 0.3759 & 66.63394 & 0.44 & 0.29060 & 0.02369 \\
\hline & Kanan & 0.3657 & 67.86066 & 0.44 & 0.33748 & 0.02801 \\
\hline \multirow{2}{*}{18} & Kiri & 0.3324 & 72.32618 & 0.44 & 0.30943 & 0.02737 \\
\hline & Kanan & 0.3415 & 71.04298 & 0.44 & 0.35595 & 0.03093 \\
\hline \multirow{2}{*}{19} & Kiri & 0.3547 & 69.26707 & 0.44 & 0.41037 & 0.03477 \\
\hline & Kanan & 0.3513 & 69.71095 & 0.44 & 1.31629 & 0.11224 \\
\hline \multirow{2}{*}{20} & Kiri & 0.2991 & 77.60513 & 0.44 & 0.71358 & 0.06774 \\
\hline & Kanan & 0.3081 & 76.07857 & 0.44 & 0.81282 & 0.07564 \\
\hline \multirow{2}{*}{21} & Kiri & 0.2943 & 78.44485 & 0.44 & 1.80183 & 0.17289 \\
\hline & Kanan & 0.2976 & 77.85363 & 0.44 & 2.79323 & 0.26600 \\
\hline \multirow{2}{*}{22} & Kiri & 0.4106 & 62.81975 & 0.44 & 0.62830 & 0.04828 \\
\hline & Kanan & 0.4106 & 62.81975 & 0.44 & 0.61617 & 0.04735 \\
\hline \multirow{2}{*}{23} & Kiri & 0.5850 & 49.61959 & 0.44 & 0.39564 & 0.02401 \\
\hline & Kanan & 0.5850 & 49.61959 & 0.44 & 0.38456 & 0.02334 \\
\hline \multirow{2}{*}{24} & Kiri & 0.4496 & 59.14085 & 0.44 & 0.09906 & 0.00717 \\
\hline & Kanan & 0.4496 & 59.14085 & 0.44 & 0.09763 & 0.00706 \\
\hline \multirow{2}{*}{25} & Kiri & 0.4760 & 56.92829 & 0.44 & 0.16965 & 0.01181 \\
\hline & Kanan & 0.4760 & 56.92829 & 0.44 & 0.17798 & 0.01239 \\
\hline \multirow{2}{*}{26} & Kiri & 0.5301 & 52.98439 & 0.44 & 0.21873 & 0.01418 \\
\hline & Kanan & 0.5301 & 52.98439 & 0.44 & 0.21792 & 0.01412 \\
\hline \multirow{2}{*}{27} & Kiri & 0.2173 & 96.02176 & 0.44 & 0.31167 & 0.03661 \\
\hline & Kanan & 0.1934 & 103.77634 & 0.44 & 0.32494 & 0.04125 \\
\hline \multirow{2}{*}{28} & Kiri & 0.1720 & 112.23030 & 0.44 & 0.06666 & 0.00915 \\
\hline & Kanan & 0.1693 & 113.42056 & 0.44 & 0.06396 & 0.00887 \\
\hline \multirow{2}{*}{29} & Kiri & 0.2547 & 86.38249 & 0.44 & 0.79399 & 0.08390 \\
\hline & Kanan & 0.2513 & 87.15585 & 0.44 & 1.71379 & 0.18271 \\
\hline \multirow{2}{*}{30} & Kiri & 0.1514 & 122.15548 & 0.44 & 0.07214 & 0.01078 \\
\hline & Kanan & 0.1476 & 124.27427 & 0.44 & 0.07239 & 0.01100 \\
\hline \multirow{2}{*}{31} & Kiri & 0.2759 & 81.89244 & 0.44 & 1.30724 & 0.13095 \\
\hline & Kanan & 0.2657 & 83.96384 & 0.44 & 3.38813 & 0.34798 \\
\hline & Kiri & 0.2215 & 94.81098 & 0.44 & 0.94356 & 0.10943 \\
\hline 3 & Kanan & 0.2112 & 97.86509 & 0.44 & 2.97390 & 0.35600 \\
\hline & Kiri & 0.1726 & 111.95265 & 0.44 & 0.07285 & 0.00998 \\
\hline 33 & Kanan & 0.1924 & 104.13932 & 0.44 & 1.18365 & 0.15078 \\
\hline & Kiri & & & & & \\
\hline 3 & Kanan & 0.2061 & 99.46199 & 0.44 & 1.10570 & 0.13452 \\
\hline & Kiri & 0.2720 & 82.67262 & 0.44 & 1.06679 & 0.10788 \\
\hline 35 & Kanan & 0.2720 & 82.67262 & 0.44 & 1.06089 & 0.10728 \\
\hline & Kiri & 0.2910 & 79.02855 & 0.44 & 0.74087 & 0.07162 \\
\hline 3 & Kanan & 0.2910 & 79.02855 & 0.44 & 0.73365 & 0.07092 \\
\hline & Kiri & 0.2753 & 82.00958 & 0.44 & 0.37436 & 0.03755 \\
\hline 37 & Kanan & 0.2753 & 82.00958 & 0.44 & 0.36119 & 0.03623 \\
\hline & Kiri & 0.4047 & 63.43055 & 0.44 & 0.27926 & 0.02167 \\
\hline 38 & Kanan & 0.4047 & 63.43055 & 0.44 & 0.26609 & 0.02065 \\
\hline
\end{tabular}


Tabel 5. Perhitungan intensitas hujan dan debit rencana (Lanjutan)

\begin{tabular}{ccccccc}
\hline $\begin{array}{c}\text { No } \\
\text { Saluran }\end{array}$ & Posisi & Tc & $\begin{array}{c}\text { Intensitas } \\
(\mathrm{mm} / \mathrm{jam})\end{array}$ & $\mathrm{C}$ & $\begin{array}{c}\text { A } \\
\text { Kumulatif } \\
(\mathrm{Ha})\end{array}$ & $\begin{array}{c}\text { Debit } \\
\left(\mathrm{m}^{3} / \mathrm{s}\right)\end{array}$ \\
\hline \multirow{2}{*}{39} & Kiri & 0.3992 & 64.01597 & 0.44 & 0.27199 & 0.02130 \\
& Kanan & 0.3992 & 64.01597 & 0.44 & 0.27793 & 0.02176 \\
40 & Kiri & 0.3859 & 65.47931 & 0.44 & 0.27206 & 0.02179 \\
& Kanan & 0.3859 & 65.47931 & 0.44 & 0.27339 & 0.02190 \\
41 & Kiri & 0.2791 & 81.26774 & 0.44 & 0.32581 & 0.03239 \\
& Kanan & 0.2822 & 80.66530 & 0.44 & 0.39668 & 0.03914 \\
42 & Kiri & 0.2593 & 85.35783 & 0.44 & 0.16639 & 0.01737 \\
& Kanan & 0.2852 & 80.09597 & 0.44 & 0.23797 & 0.02332 \\
43 & Kiri & 0.1822 & 108.00314 & 0.44 & 0.05071 & 0.00670 \\
& Kanan & 0.1837 & 107.38784 & 0.44 & 0.05071 & 0.00666 \\
44 & Kiri & & & & & \\
& Kanan & 0.2396 & 89.96977 & 0.44 & 0.06624 & 0.00729 \\
45 & Kiri & 0.3459 & 70.43666 & 0.44 & 0.08854 & 0.00763 \\
& Kanan & 0.3459 & 70.43666 & 0.44 & 0.09183 & 0.00791 \\
46 & Kiri & 0.3815 & 65.98431 & 0.44 & 0.10097 & 0.00815 \\
& Kanan & 0.3815 & 65.98431 & 0.44 & 0.10263 & 0.00828 \\
47 & Kiri & 0.4334 & 60.60046 & 0.44 & 0.22326 & 0.01655 \\
& Kanan & 0.4334 & 60.60046 & 0.44 & 0.22448 & 0.01664 \\
\hline
\end{tabular}

Bedasarkan perhitungan intensitas hujan dan debit rencana periode 2 tahun terdapat 13 dari 84 saluran yang tidak memenuhi yang dapat dilihat dalam Gambar 3.

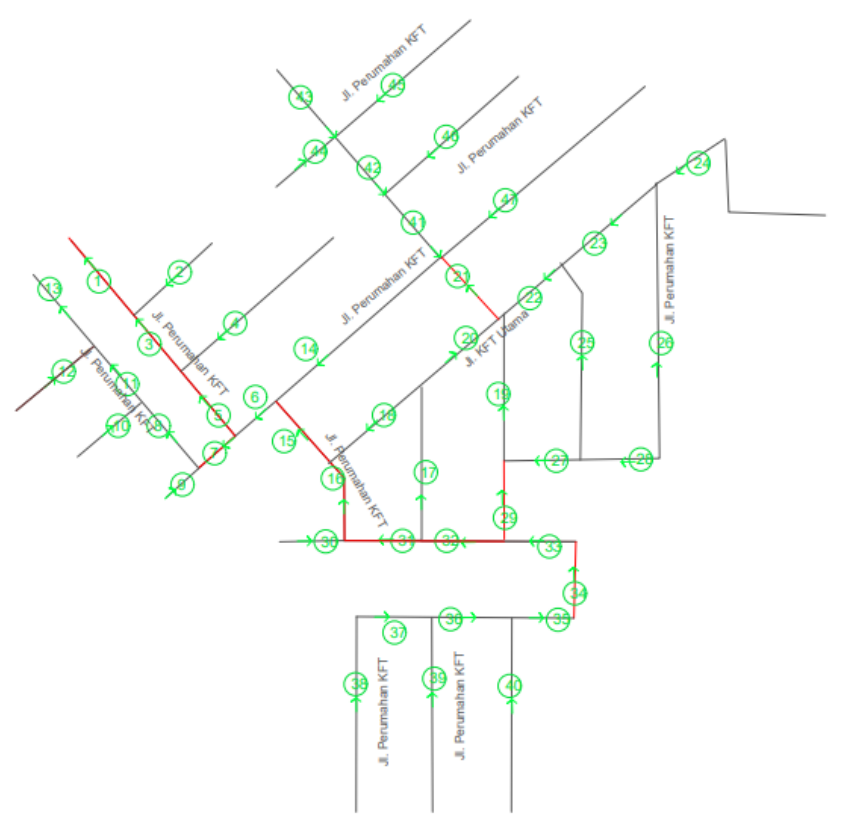

Gambar 3. Peta jaringan drainase wilayah Perumahan KFT terhadap saluran yang tidak memenuhi.

Bedasarkan gambar di atas, diketahui terdapat 13 saluran yang tidak memenuhi yaitu saluran 1 kiri,3 kiri,5 kiri,7 kiri,15 kiri,16 kiri,21 kanan,29 kanan, 31 kiri kanan, 32 kiri kanan, dan 34 kanan..Maka dari itu diperlukan perubahan dimensi saluran guna menambah kapasitas debit saluran tersebut. Dengan menggunakan metode Trial and Error maka dapat dilihat dimensi yang dapat dilihat pada Tabel 6. 
Tabel 6. Perhitungan debit eksisting dengan dimensi baru dan perbandingan dengan dimensi lama.

\begin{tabular}{|c|c|c|c|c|c|c|c|c|c|}
\hline \multirow{2}{*}{ No } & \multirow{2}{*}{ Posisi } & \multirow{2}{*}{$\begin{array}{l}\text { Panjang } \\
(\mathrm{m})\end{array}$} & \multicolumn{2}{|c|}{ Baru } & \multicolumn{2}{|c|}{ Lama } & \multirow{2}{*}{$\begin{array}{c}\text { Debit } \\
\text { Rencana }\end{array}$} & \multicolumn{2}{|c|}{ Debit Eksisting } \\
\hline & & & Lebar (m) & Kedalaman (m) & Lebar (m) & Kedalaman (m) & & Baru & Lama \\
\hline 1 & Kiri & 42.83 & 0.6 & 1.2 & 0.6 & 0.8 & 0.5425 & 0.5454 & 0.2975 \\
\hline 3 & Kiri & 40.56 & 0.6 & 1.2 & 0.6 & 0.8 & 0.5363 & 0.5604 & 0.1839 \\
\hline 5 & Kiri & 40.87 & 0.6 & 1.2 & 0.6 & 0.8 & 0.5248 & 0.5583 & 0.1832 \\
\hline 7 & Kiri & 21.16 & 0.6 & 1 & 0.6 & 0.6 & 0.3337 & 0.4632 & 0.1353 \\
\hline 15 & Kiri & 40.89 & 0.5 & 0.75 & 0.5 & 0.55 & 0.1680 & 0.2102 & 0.0877 \\
\hline 16 & Kiri & 48.56 & 0.5 & 0.75 & 0.5 & 0.55 & 0.1577 & 0.1929 & 0.0805 \\
\hline 21 & Kanan & 48.55 & 0.6 & 0.85 & 0.6 & 0.65 & 0.2660 & 0.3644 & 0.1517 \\
\hline 29 & Kanan & 48.9 & 0.6 & 1.05 & 0.6 & 0.65 & 0.1827 & 0.3779 & 0.1143 \\
\hline 31 & Kiri & 50.96 & 0.4 & 1.05 & 0.4 & 0.65 & 0.1309 & 0.2001 & 0.0640 \\
\hline 31 & Kanan & 50.96 & 0.5 & 1.15 & 0.5 & 0.75 & 0.3480 & 0.1883 & 0.1172 \\
\hline 32 & Kiri & 47.26 & 0.4 & 1.05 & 0.4 & 0.65 & 0.0100 & 0.1034 & 0.0664 \\
\hline 32 & Kanan & 47.26 & 0.5 & 1.15 & 0.5 & 0.75 & 0.3560 & 0.1955 & 0.1217 \\
\hline 34 & Kanan & 49.46 & 0.4 & 0.95 & 0.4 & 0.65 & 0.1345 & 0.1083 & 0.0726 \\
\hline
\end{tabular}

Pemodelan saluran nomor 21 saluran eksisting dan saluran rencana dilakukan dengan aplikasi HEC-RAS dengan memperhatikan Hilir dan Hulu di sebelah kanan. Pemodelan dapat dilihat dalam Gambar 4 dan 5.

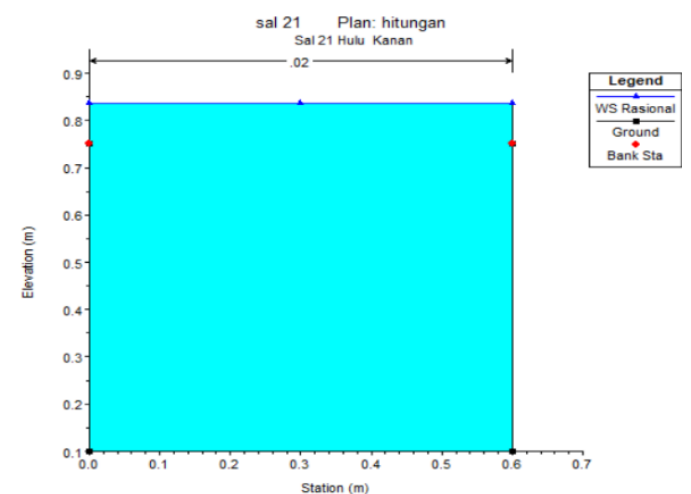

Gambar 4. Ketinggian Muka Air Saluran 21 Kanan Hulu Lama

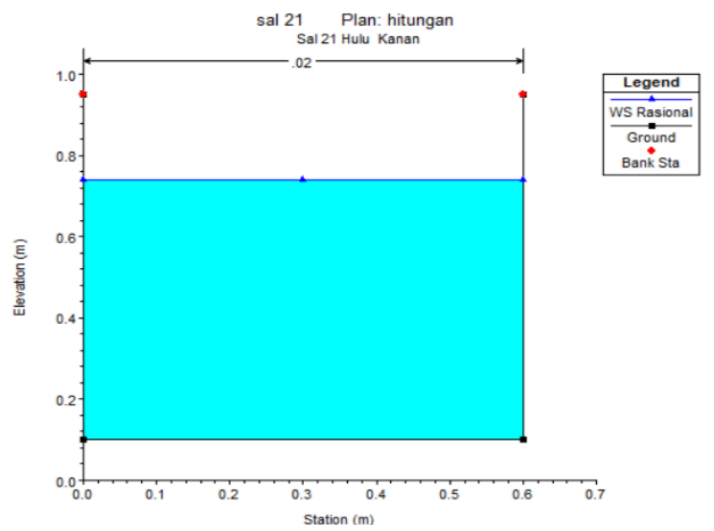

Gambar 5. Ketinggian Muka Air Saluran 21 Kanan Hulu Baru

Pada gambar 4 dan 5, titik yamg berwarna merah adalah batas tinggi saluran, titik yang bewarna hitam adalah batas permukaan dasar saluran, sedangkan warna biru adalah besar debit air yang terjadi. Dari hasil pemodelan dapat dilihat saluran eksisting (gambar 4) tidak mampu menampung debit limpasan, sedangkan saluran rencana (gambar 5) dapat menapung debit limpasan.

Di Perumahan KFT terdapat 1 buah pompa dengan kapasitas $1 \mathrm{~m} / \mathrm{s}$ dan 1 buah pompa dengan kapasitas $0,3 \mathrm{~m} 3 / \mathrm{s}$. Debit pompa diambil dari debit saluran eksisting dan debit saluran limpasan dari Waduk KFT. Penjabarannya ditampilkan Tabel 7. Grafik ditampilkan dalam gambar 6 dan 7. 
Tabel 7. Massa inflow dan outflow pompa

\begin{tabular}{|c|c|c|c|c|c|c|c|c|c|c|c|}
\hline $\begin{array}{l}\text { Waktu } \\
\text { (jam) }\end{array}$ & $\begin{array}{l}\text { Waktu } \\
\text { (menit) }\end{array}$ & $\begin{array}{l}\text { Waktu } \\
\text { (detik) }\end{array}$ & $\begin{array}{l}\text { delta T } \\
\text { (menit) }\end{array}$ & $\begin{array}{l}\text { delta T } \\
\text { (detik) }\end{array}$ & $\begin{array}{l}\text { Debit } \\
\text { Inflow }\end{array}$ & $\begin{array}{l}\text { Debit } \\
\text { Outflow }\end{array}$ & $\begin{array}{l}\text { Massa } \\
\text { Inflow }\end{array}$ & $\begin{array}{c}\text { Massa } \\
\text { Inflow + }\end{array}$ & $\begin{array}{l}\text { Massa } \\
\text { Outflow }\end{array}$ & $\begin{array}{c}\text { Massa } \\
\text { Outflow } \\
+\end{array}$ & $\mathrm{I}-\mathrm{O}$ \\
\hline 0 & 0 & 0 & 0 & 0 & 0 & 0 & 0 & 0 & 0 & 0 & 0 \\
\hline 0.1 & 6 & 360 & 6 & 360 & 0.2133 & 0 & 76.7916 & 76.7916 & 0 & 0 & 76.7916 \\
\hline 0.2 & 12 & 720 & 12 & 360 & 0.4266 & 0 & 153.5832 & 230.3748 & 0 & 0 & 230.3748 \\
\hline 0.3 & 18 & 1080 & 18 & 360 & 0.6399 & 1 & 230.3748 & 460.7496 & 360 & 360 & 100.7496 \\
\hline 0.4 & 24 & 1440 & 24 & 360 & 0.8532 & 1 & 307.1664 & 767.916 & 360 & 720 & 47.916 \\
\hline 0.5 & 30 & 1800 & 30 & 360 & 1.0666 & 1 & 383.958 & 1151.874 & 360 & 1080 & 71.874 \\
\hline 0.6 & 36 & 2160 & 36 & 360 & 1.2799 & 1.3 & 460.7496 & 1612.6236 & 468 & 1548 & 64.6236 \\
\hline 0.7 & 42 & 2520 & 42 & 360 & 1.4932 & 1.3 & 537.5412 & 2150.1648 & 468 & 2016 & 134.1648 \\
\hline 0.8 & 48 & 2880 & 48 & 360 & 1.7065 & 1.3 & 614.3328 & 2764.4976 & 468 & 2484 & 280.4976 \\
\hline 0.9 & 54 & 3240 & 54 & 360 & 1.9198 & 1.3 & 691.1244 & 3455.622 & 468 & 2952 & 503.622 \\
\hline 1 & 60 & 3600 & 60 & 360 & 2.0264 & 1.3 & 729.5202 & 4185.1422 & 468 & 3420 & 765.1422 \\
\hline 1.05 & 63 & 3780 & 63 & 360 & 2.1331 & 1.3 & 767.916 & 4953.0582 & 468 & 3888 & 1065.0582 \\
\hline 1.1 & 66 & 3960 & 66 & 360 & 2.0264 & 1.3 & 729.5202 & 5682.5784 & 468 & 4356 & 1326.5784 \\
\hline 1.2 & 72 & 4320 & 72 & 360 & 1.9198 & 1.3 & 691.1244 & 6373.7028 & 468 & 4824 & 1549.7028 \\
\hline 1.3 & 78 & 4680 & 78 & 360 & 1.7065 & 1.3 & 614.3328 & 6988.0356 & 468 & 5292 & 1696.0356 \\
\hline 1.4 & 84 & 5040 & 84 & 360 & 1.4932 & 1.3 & 537.5412 & 7525.5768 & 468 & 5760 & 1765.5768 \\
\hline 1.5 & 90 & 5400 & 90 & 360 & 1.2799 & 1.3 & 460.7496 & 7986.3264 & 468 & 6228 & 1758.3264 \\
\hline 1.6 & 96 & 5760 & 96 & 360 & 1.0666 & 1 & 383.958 & 8370.2844 & 360 & 6588 & 1782.2844 \\
\hline 1.7 & 102 & 6120 & 102 & 360 & 0.8532 & 1 & 307.1664 & 8677.4508 & 360 & 6948 & 1729.4508 \\
\hline 1.8 & 108 & 6480 & 108 & 360 & 0.6399 & 1 & 230.3748 & 8907.8256 & 360 & 7308 & 1599.8256 \\
\hline 1.9 & 114 & 6840 & 114 & 360 & 0.4266 & 0 & 153.5832 & 9061.4088 & 0 & 7308 & 1753.4088 \\
\hline 2 & 120 & 7200 & 120 & 360 & 0.2133 & 0 & 76.7916 & 9138.2004 & 0 & 7308 & 1830.2004 \\
\hline 2.1 & 126 & 7560 & 126 & 360 & 0 & 0 & 0 & 9138.2004 & 0 & 7308 & 1830.2004 \\
\hline
\end{tabular}

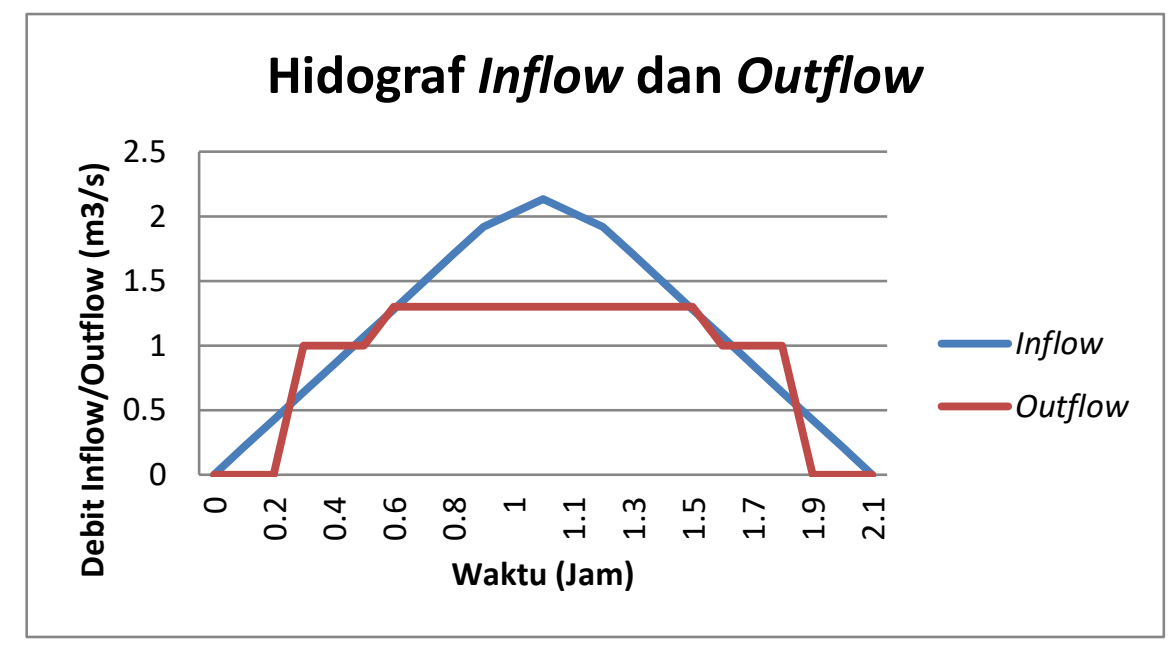

Gambar 6. Hidograf inflow dan outflow pompa di Waduk KFT 


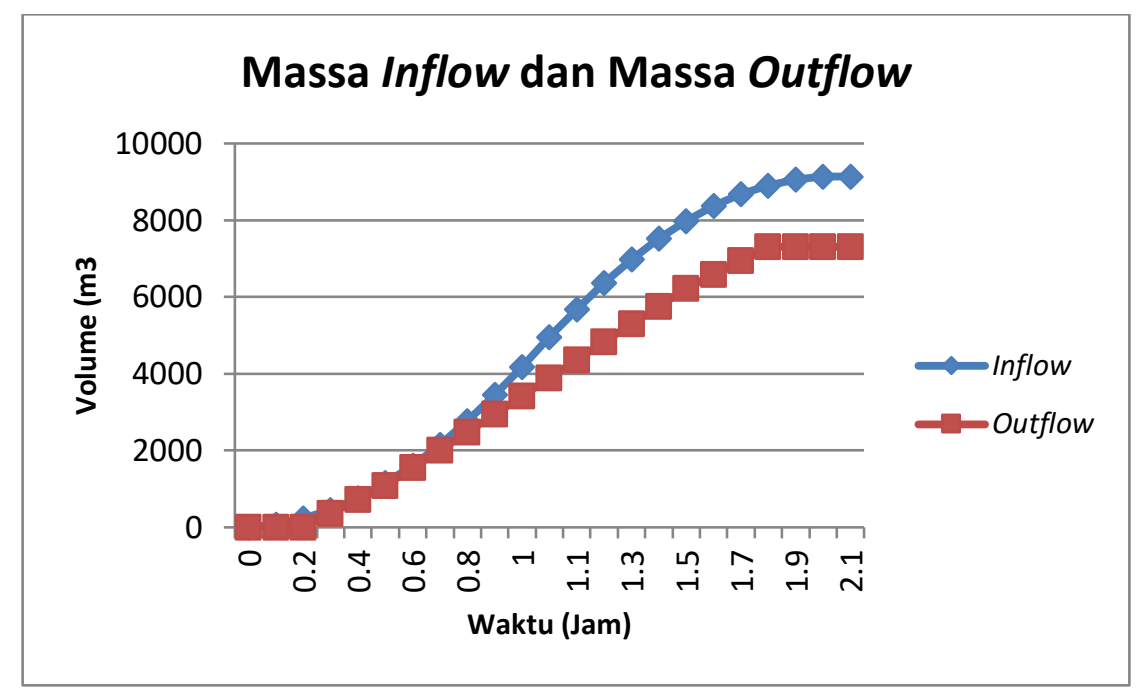

Gambar 7. Massa inflow dan Massa outflow pompa di Waduk KFT

Gambar 6 dan 7 merupakan pembuatan hidograf banjir dilakukan dengan hidograf segitiga, dimana dilakukan perbandingan massa inflow dan massa outflow serta debit inflow dan debit outflow. Debit inflow merupakan debit yang didapatkan dari dari curah hujan sementara debit outflow merupakan debit yang akan dikeluarkan dengan bantuan pompa. Gambar 6 dan 7 memberikan penjelasan bahwa debit curah hujan lebih besar daripada debit yang akan dikeluarkan oleh pompa yang akan ditampung di dalam kolam penampungan KFT.

\section{KESIMPULAN DAN SARAN}

\section{Kesimpulan}

1. Kapasitas saluran eksisting pada tanggal 1-3 Januari 2020 terdapat 23 saluran yang tidak memenuhi dan 61 saluran yang memenuhi.

2. Periode Curah Hujan yang digunakan yaitu periode 2 tahun dengan metode Chi-Square Log Pearson III.

3. Permasalahan banjir pada sistem drainase kawasan Perumahan KFT - Cengkareng Barat disebabkan oleh ketidakmampuan beberapa saluran drainase menampung dan mengalirkan debit yang melimpas. Selain itu juga disebabkan oleh kontur yang mempunyai ketinggian sama dengan nilai antara 0,0002 sampai 0,005 .

4. Solusi yang dapat dilakukan untuk menanggulangi banjir di Perumahan KFT - Cengkareng Barat adalah dengan mengubah dimensi saluran drainase (tabel 6)dan menambah pompa.

\section{Saran}

Berdasarkan hasil analisis yang telah dilakukan disarankan untuk melakukan normalisasi saluran secara berkala. Selain itu juga diperlukan sosialisasi yang dilakukan oleh kepala desa atau pemerintah daerah kepada masyarakat dan warga mengenai penjagaan kualitas saluran dan penanganan banjir yang baik dan tepat.

\section{DAFTAR PUSTAKA}

Badan Standarisasi Nasional. SNI 2415:2016 (Tata Cara Perhitungan Debit Banjir Recana). Badan Standardisasi Nasional, 2016.

Dinas Komunikasi, Informatika dan Statistik Pemprov DKI Jakarta. Data jumlah penduduk kelurahan Cengkareng Barat. Portal Resmi Provinsi DKI Jakarta, 2020.

Haryono, Yosef. Drainase. Jakarta: Jurusan Teknik Sipil-Fakultas Teknik Universitas Tarumanagara, 2016.

Istiarto. Simulasi aliran 1-dimensi dengan bantuan paket program hidrodinamika HEC-RAS. Departemen Teknik Sipil dan Lingkungan Fakultas Teknik UGM, 2014.

Menteri Pekerjaan Umum. Peraturan Menteri Pekerjaan Umum Nomor 12/PRT/M/2014. Kementerian Pekerjaan Umum, 2014.

Suku Dinas Sumber Daya Air Kota Jakarta Barat. Sebaran Titik Banjir kelurahan Cengkareng Barat. Sumber Daya Air Kota Jakarta Barat, 2020.

Suripin. Sistem Drainase Yang Berkelanjutan. Andi, 2004.

Upono, et al. "Pemilihan Distribusi Probabilitas Pada Analisa Hujan dengan Metode Goodness of Fit Test." Jurnal Teknik Sipil dan Perencanaan, vol. 18, no. 2, 2016, pp. 141-143. 
Analisis Penyebab Banjir dan Solusinya pada Perumahan

Christian, et al. KFT-Cengkareng Barat 